OPEN ACCESS

Edited by:

Vincent Tropepe,

University of Toronto, Canada

Reviewed by:

Seiji Hitoshi,

Shiga University of Medical Science,

Japan

Cindi M. Morshead

University of Toronto, Canada

*Correspondence:

Claude Messier

cmessier@uottawa.ca

Specialty section: This article was submitted to

Neurogenesis,

a section of the journal

Frontiers in Neuroscience

Received: 27 September 2016 Accepted: 07 March 2017

Published: 28 March 2017

Citation:

Boulanger JJ and Messier C (2017) Doublecortin in Oligodendrocyte

Precursor Cells in the Adult Mouse Brain. Front. Neurosci. 11:143. doi: 10.3389/fnins.2017.00143

\section{Doublecortin in Oligodendrocyte Precursor Cells in the Adult Mouse Brain}

\author{
Jenna J. Boulanger and Claude Messier* \\ School of Psychology, University of Ottawa, Ottawa, ON, Canada
}

\section{Key Points}

- Oligodendrocyte precursor cells express doublecortin, a microtubule-associated protein.

- Oligodendrocyte precursor cells express doublecortin, but at a lower level of expression than in neuronal precursor.

- Doublecortin is not associated with a potential immature neuronal phenotype in Oligodendrocyte precursor cells.

Oligodendrocyte precursor cells (OPC) are glial cells that differentiate into myelinating oligodendrocytes during embryogenesis and early stages of post-natal life. OPCs continue to divide throughout adulthood and some eventually differentiate into oligodendrocytes in response to demyelinating lesions. There is growing evidence that OPCs are also involved in activity-driven de novo myelination of previously unmyelinated axons and myelin remodeling in adulthood. Considering these roles in the adult brain, OPCs are likely mobile cells that can migrate on some distances before they differentiate into myelinating oligodendrocytes. A number of studies have noted that OPCs express doublecortin (DCX), a microtubule-associated protein expressed in neural precursor cells and in migrating immature neurons. Here we describe the distribution of DCX in OPCs. We found that almost all OPCs express DCX, but the level of expression appears to be much lower than what is found in neural precursor. We found that DCX is downregulated when OPCs start expressing mature oligodendrocyte markers and is absent in myelinating oligodendrocytes. DCX does not appear to signal an immature neuronal phenotype in OPCs in the adult mouse brain. Rather, it could be involved either in cell migration, or as a marker of an immature oligodendroglial cell phenotype.

Keywords: myelin, adult neurogenesis, myelin remodeling, oligodendrocyte, plasticity, gliogenesis, cell migration

\section{INTRODUCTION}

Although traditionally perceived as non-regenerative tissue, the adult brain does retain the ability to generate new neurons, as first described by Messier (Messier et al., 1958) and confirmed by Altman and Das (1964). More specifically, studies have determined that neurogenesis in the adult rodent brain takes place in two distinct regions: the subgranular layer of the dentate gyrus of the hippocampus, with newly generated neurons migrating to the granular layer of the dentate gyrus (Kaplan and Bell, 1984; Stanfield and Trice, 1988; Cameron et al., 1993; Kuhn et al., 1996) and in the 
subventricular zone of the lateral ventricles, from where the newly generated neurons migrate to the olfactory bulbs using a pathway known as the rostral migratory stream (Lois and Alvarez-Buylla, 1994; Alvarez-Buylla and Garcia-Verdugo, 2002).

The migration of these newly generated neuroblasts to their final destination is thought to be facilitated by the expression of doublecortin (DCX), a protein that participates in the polymerization of microtubules (Francis et al., 1999; Gleeson et al., 1999). DCX is only transiently expressed in proliferating progenitor cells and in newly generated neuroblasts and its expression is downregulated as the cells begin to express markers of a mature neuronal state. This has led to the use of DCX as a selective marker of adult neurogenesis (Brown et al., 2003). However, DCX expression is not restricted to the dentate gyrus or areas involved in the addition of new neurons to the olfactory bulbs (Nacher et al., 2001; Dayer et al., 2005; Luzzati et al., 2006; Xiong et al., 2008; Cai et al., 2009; Klempin et al., 2011; Werner et al., 2012; Saul et al., 2014). Some authors have also observed DCX in cells expressing immature neurons markers located in the layer III of the piriform cortex and endopiriform nucleus of adult rodents which do not appear to be migrating neurons (Rivers et al., 2008; Guo F. et al., 2010; Klempin et al., 2011; Clarke et al., 2012). Finally, as we show here, DCX is widely expressed in oligodendrocyte precursor cells (OPCs; also known as NG2glial cells, synantocytes, or polydendrocytes; Tamura et al., 2007a; Ehninger et al., 2011).

OPCs are a type of glial cell that give rise, as their name suggests, to myelinating oligodendrocytes during embryogenesis and early stages of post-natal life (Nishiyama et al., 2002). However, a large number of OPCs maintain their undifferentiated state after these initial developmental stages and OPCs are thus abundant in the adult brain, corresponding to $\sim 5-8 \%$ of the total cell population (Dawson et al., 2003; Gallo et al., 2008). Adult OPCs form non-overlapping fields that are uniformly distributed between the gray and white matter of the central nervous system (Dawson et al., 2003; De Biase et al., 2010; Kukley et al., 2010; Hughes et al., 2013). While their proliferative activity does decline with age, they continue to undergo cell division throughout adulthood, representing the most active population of cycling cells within the adult brain (Dawson et al., 2003; Psachoulia et al., 2009). The fate of these adult-generated OPCs has not been clearly established (Boulanger and Messier, 2014). While most daughter cells appear to maintain an OPC phenotype, it has been demonstrated that a subset of these cells differentiates into a mature myelinating oligodendroglial phenotype (Dimou et al., 2008; Kang et al., 2010; Clarke et al., 2012). Furthermore, some researchers have reported that postnatal OPCs are multipotent and have the capacity to differentiate into astrocytes and neurons in multiple regions of the adult CNS (Belachew et al., 2003; Aguirre and Gallo, 2004; Aguirre et al., 2004; Dayer et al., 2005; Tamura et al., 2007a; Rivers et al., 2008; Zhu et al., 2008; Guo F. Z. et al., 2009,

Abbreviations: DCX, Doublecortin; GST $\pi$, glutathione S-transferase pi; NG2, chondroitin sulfate proteoglycan neuron-glia antigen 2; Olig1, bHLH transcription factor 1; OPC, oligodendrocyte precursor cell; PDGFR $\alpha$, platelet-derived growth factor receptor alpha; Sox10, SRY-related HMG-box transcription factor 10.
2010; Robins et al., 2013). However, this ability to differentiate into neurons is not supported by other studies (Dimou et al., 2008; Komitova et al., 2009; Kang et al., 2010; Richardson et al., 2011; Zhu et al., 2011; Nishiyama et al., 2016). This remains a debated point at this time (Larson et al., 2016; Nishiyama et al., 2016; Viganò and Dimou, 2016).

Here, we show that despite evidence for multipotency in OPCs, DCX is not associated with an immature neuronal phenotype in these cells. Rather, it could be involved either in cell migration, or as a marker of an immature oligodendroglial cell phenotype.

\section{MATERIALS AND METHODS}

\section{Animals}

Animals were 4-5 month old Long-Evans rats (Charles River, St-Constant, Qc, Canada), 5-10 weeks old CD-1 mice (Charles River, St-Constant, Qc, Canada), and 3-5 month-old C57BL/6J mice (Jackson Laboratory, Bar Harbor, Maine, USA) All the animals used in this study were individually housed in a $21 \pm$ $1^{\circ} \mathrm{C}$ vivarium, maintained on a 12 -h light/dark cycle, and had ad libitum access to food and water. All animal procedures were done in accordance with the recommendations of the Canadian Council on Animal Care and were approved by the Animal Care Committee of the University of Ottawa.

\section{Transgenic Animals}

NG2CreER BAC transgenic mice (Jackson Laboratory, Bar Harbor, Maine, USA; described in Zhu et al., 2011) were bred in house with R26-stop-EYFP transgenic mice on a C57BL/6J background (Jackson Laboratory, Bar Harbor, Maine, USA) to generate the NG2-CreER:EYFP reporter mouse. Three to fivemonth old animals $(n=8)$ received i.p injections of $6 \mathrm{mg}$ of tamoxifen per day, over a period of 5 days. Six days after the last tamoxifen injection, the animals' drinking water was replaced with 5-bromo- $2^{\prime}$-deoxyuridine (BrdU) in sweetened water (100 $\mathrm{ml}$ water $+0.125 \mathrm{~g}$ saccharine $+3 \mathrm{~g}$ dextrose $+0.1 \mathrm{~g}$ BrdU) for a total of 8 days. Mice were perfused 8 weeks following the end of BrdU exposure.

\section{Tissue Processing}

Anesthetized rats or mice were transcardially perfused with saline followed by Lana's fixative (4\% paraformaldehyde-picric acid; modified from Zamboni and Demartin, 1967). Brains were postfixed in this fixative for $1 \mathrm{~h}$ before being incubated in $10 \%$ sucrose in sodium phosphate buffer $(0.1 \mathrm{M}, \mathrm{pH} 7.2)$ overnight at $4^{\circ} \mathrm{C}$. Brains were then frozen using $\mathrm{CO}_{2}$ and cut in $14 \mu \mathrm{m}$ sagittal sections using a cryostat.

\section{Immunochemistry \\ Peptide Competition Assay}

To determine the specificity of the goat anti-DCX antibody (Santa Cruz, sc-8066) and the guinea-pig anti-DCX antibody (Chemicon, AB5910) a peptide competition assay was performed. The DCX peptide was no longer available at Chemicon. As such, both antibodies were submitted to a competition assay with the DCX peptide provided by Santa Cruz 
Biotechnology (sc-8066). A 1:5 solution of anti-DCX antibody and anti-DCX peptide (sc-8066P, Santa Cruz) was incubated at room temperature for $1 \mathrm{~h}$. The preparation was then diluted in $0.3 \%$ Triton and each section was covered with $50 \mu \mathrm{l}$ and incubated at room temperature for $3 \mathrm{~h}$. Following incubation, slides were washed successively three times for $5 \mathrm{~min}$ in PBS $(10 \mathrm{mM})$. Each section was then incubated for $30 \mathrm{~min}$ at $37^{\circ} \mathrm{C}$ with $50 \mu \mathrm{l}$ of the secondary antibody Alexa488 donkey anti-Goat (1:1,000, Invitrogen) or Alexa488 anti-guinea pig (1:500, Jackson Immuno Research) diluted in $0.3 \%$ Triton in 10X PBS. After incubation, slides were washed successively three times for $5 \mathrm{~min}$ in 10X PBS. Sections were imbedded in custom-made anti-fade solution (p-Phenylenediamine and glycerol in PBS solution) and cover-slipped with micro cover glasses (VWR Scientific).

\section{Primary Antibodies}

Antibodies used and dilutions are presented in Table 1. Primary antibody solutions were diluted in $0.3 \%$ Triton in 10X PBS. Tissue sections were covered with $50 \mu \mathrm{l}$ of the primary antibody solution and parafilm was placed on top to prevent evaporation. Slides were incubated at room temperature in a humidified chamber for $3 \mathrm{~h}$. Following incubation, slides were washed successively three times for $5 \mathrm{~min}$ in 10X PBS. An anti-GFP antibody that also recognize EYFP was used to label the NG2-CreER:EYFPpositive OPCs because it improved visualization of the EYFP NG2 reporter.

\section{Secondary Antibodies}

Antibodies used and dilutions are presented in Table 1. Secondary antibody solutions were diluted in $0.3 \%$ Triton in $10 \mathrm{X}$ PBS. Tissue sections were covered with $50 \mu \mathrm{l}$ of the secondary antibody solution and parafilm was placed on top to prevent evaporation. Slides were incubated in a humidified chamber for $30 \mathrm{~min}$ at $37^{\circ} \mathrm{C}$. Following incubation, slides were washed successively three times for $5 \mathrm{~min}$ in 10X PBS.

\section{Cell Nuclei Staining}

Cell nuclei were stained using the DNA stain Hoechst 33342 (Invitrogen). The Hoechst dye was diluted in $0.3 \%$ Triton in 10X PBS to yield a final concentration of 1:20,000. Each section was covered with $100 \mu \mathrm{l}$ of this solution and was left to incubate for $10 \mathrm{~min}$ in a humidified chamber at room temperature. Slides were washed successively three times for $5 \mathrm{~min}$ in 10X PBS. Sections were imbedded in custom-made anti-fade solution ( $\mathrm{p}$ Phenylenediamine and glycerol in PBS solution) and coverslipped.

\section{BrdU Immunostaining}

To preserve DCX and other immunostaining during the acid/heat denaturation step required for BrdU labeling, a previously described protocol was used (Boulanger et al., 2016). Immunohistochemistry for DCX and GFP were conducted first. This was followed by an overnight post-fixation step where slides were incubated in a humid chamber with Lana's fixative overnight at $4^{\circ} \mathrm{C}$. Slides were then rinsed in 10X PBS 3 times for $5 \mathrm{~min}$. This post-fixation step allowed the preservation of the DCX and GFP immunohistochemistry during the acid/heat denaturation step required for BrdU labeling. This was followed
TABLE 1 | List of antibodies used.

\begin{tabular}{|c|c|c|c|}
\hline \multicolumn{4}{|c|}{ Primary antibodies } \\
\hline Host & Target & Concentration & Company \\
\hline Rabbit & GFP (EYFP) & $1 / 1,000$ & Abcam (ab290) \\
\hline Rabbit & $\mathrm{PDGFR}_{\alpha}$ & $1 / 250$ & Santa Cruz (sc-338) \\
\hline Rat & $\mathrm{PDGFR}_{\alpha}$ & $1 / 500$ & Abcam (ab93531) \\
\hline Rabbit & $\mathrm{GST}_{\pi}$ & $1 / 500$ & MBL (311-h) \\
\hline Goat & DCX & $1 / 100$ & Santa Cruz (sc-8066) \\
\hline Guinea Pig & DCX & $1 / 500$ & Chemicon (AB5910) \\
\hline Rabbit & DCX & $1 / 1,000$ & Abcam (Ab18723) \\
\hline Mouse & Rbfox3 (NeuN) & $1 / 500$ & Millipore (MAB377) \\
\hline Goat & Sox10 & $1 / 500$ & Santa Cruz (sc-17342) \\
\hline Rat & BrdU & $1 / 500$ & Abcam (ab6326) \\
\hline Mouse & OLIG1 & $1 / 1,000$ & Millipore (MAB5540) \\
\hline Donkey & Anti-Rabbit Alexa 488 & $1 / 1,000$ & Invitrogen \\
\hline Donkey & Anti-Goat Alexa 488 & $1 / 1,000$ & Invitrogen \\
\hline Donkey & $\begin{array}{l}\text { Anti-Guinea Pig Alexa } \\
488\end{array}$ & $1 / 500$ & $\begin{array}{l}\text { Jackson immuno } \\
\text { research }\end{array}$ \\
\hline Donkey & Anti-Rabbit Alexa 594 & $1 / 1,000$ & Invitrogen \\
\hline Donkey & $\begin{array}{l}\text { Anti-Mouse Alexa } \\
594\end{array}$ & $1 / 1,000$ & Invitrogen \\
\hline Donkey & Anti-Goat Alexa 594 & $1 / 1,000$ & Invitrogen \\
\hline Donkey & Anti-Rat Alexa 594 & $1 / 1,000$ & Invitrogen \\
\hline Donkey & Anti-Rabbit Alexa 680 & $1 / 500$ & Invitrogen \\
\hline Donkey & $\begin{array}{l}\text { Anti-Mouse Alexa } \\
680\end{array}$ & $1 / 500$ & Invitrogen \\
\hline Donkey & $\begin{array}{l}\text { Anti-Guinea Pig Alexa } \\
680\end{array}$ & $1 / 500$ & $\begin{array}{l}\text { Jackson immuno } \\
\text { research }\end{array}$ \\
\hline Donkey & Anti-Rat Alexa 680 & $1 / 500$ & Abcam \\
\hline
\end{tabular}

by DNA denaturation, where slides were incubated in $\mathrm{HCl} 2 \mathrm{~N}$ for $30 \mathrm{~min}$ at $37^{\circ} \mathrm{C}$. Slides were then rinsed 3 times for $5 \mathrm{~min}$ in a $0.1 \mathrm{M}$ borate buffer $\mathrm{pH} 8$ and 3 times in $10 \mathrm{X}$ PBS for $5 \mathrm{~min}$. For BrdU immunohistochemistry, slides were incubated in a humid chamber with a rat anti-BrdU antibody dissolved in PBS with $0.3 \%$ Triton- $\mathrm{X}$ in the dark for $3 \mathrm{~h}$ at room temperature. Finally, slides were incubated in a humid chamber with a donkey anti-rat secondary antibody dissolved in PBS with $0.3 \%$ Triton$\mathrm{X}$ for $30 \mathrm{~min}$ at $37^{\circ} \mathrm{C}$. Slides were then rinsed in PBS 3 times for $5 \mathrm{~min}$, treated with custom-made anti-fade solution (pPhenylenediamine and glycerol in PBS solution) and coverslipped.

\section{Microscopy}

Immunofluorescence results were visualized using an Olympus BX51 fluorescence microscope (Olympus Corporation, Tokyo, Japan) attached to a ProgRes MF Scan camera (Jenoptik, Jena, Thuringe, Germany). Digital images were captured using the ProgRes CapturePro 2.5 software (Jenoptik, Jena, Thuringe, Germany). High-resolution observations were carried out on an Olympus FV1000 BX61 laser scan confocal microscope (Olympus Corporation, Tokyo, Japan) and images were captured using the Olympus Fluoview software (Olympus Corporation, Tokyo, Japan). 

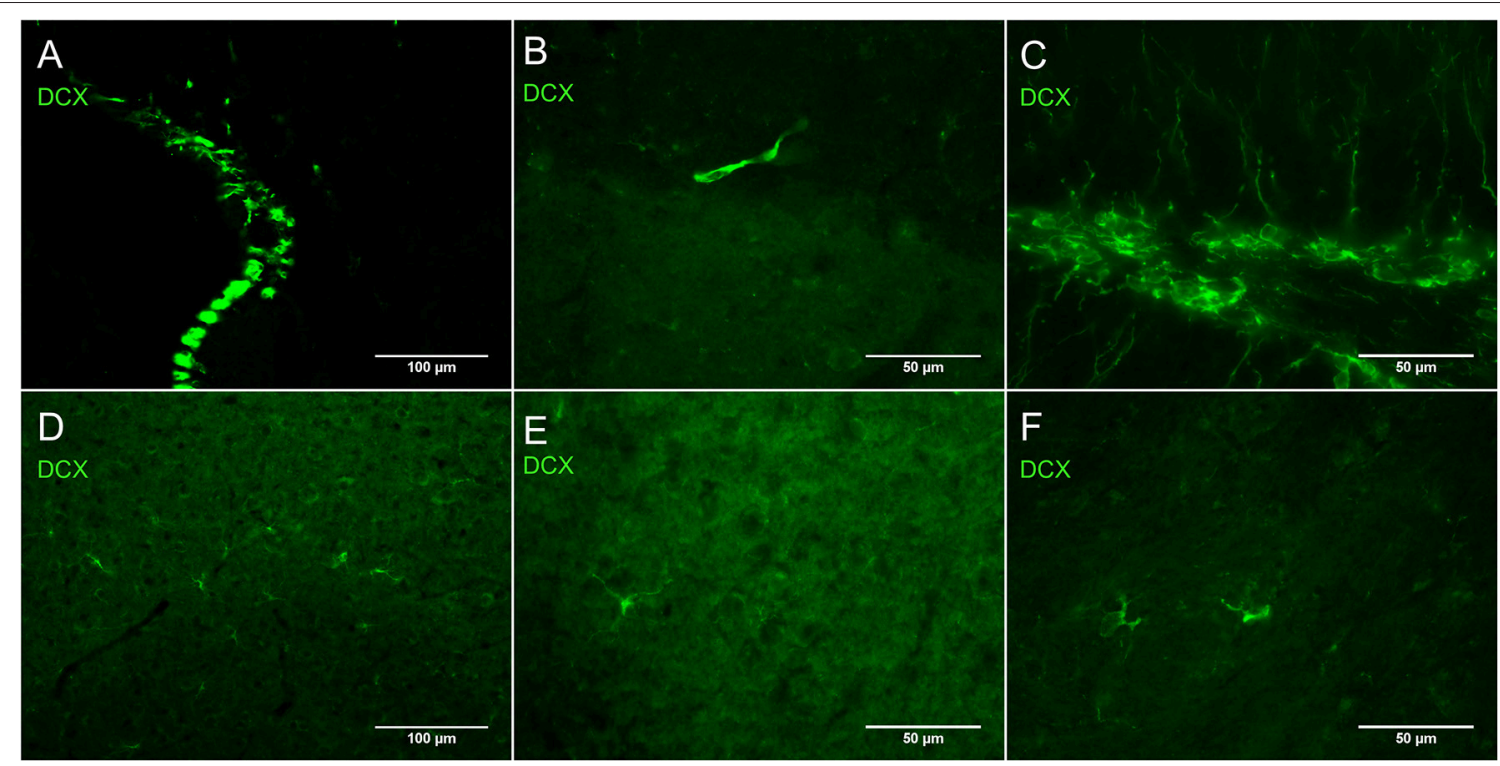

FIGURE 1 | Intensity of DCX immunostaining in neurogenic (A-C) and in non-neurogenic zones (D-F) using guinea pig anti-DCX and Alexa 488 anti-guinea pig antibodies. Exposure times for DCX labeling in non-neurogenic areas were in general double those of neurogenic areas. Pictures taken with a fluorescence microscope in the subventricular zone (A, 20X), rostral migratory stream (B, 40X), subgranular zone of the dentate gyrus (C, 40X), cortex (D, 20X), cortex (E, 40X), and striatum (F, 40X).

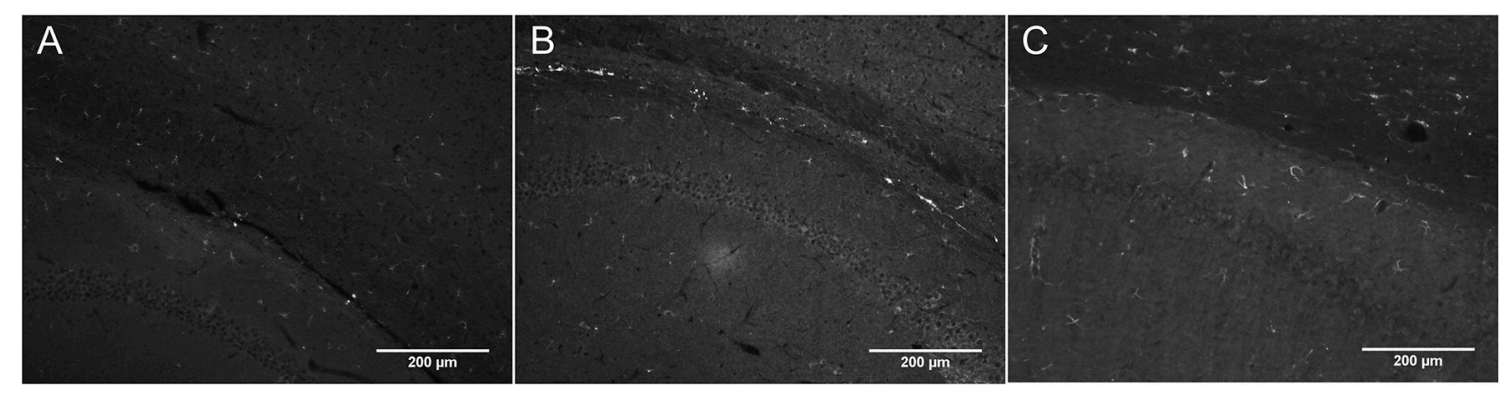

FIGURE 2 | DCX immunostaining in corpus callosum and hippocampus of rat (A) and mouse brain (B,C) at 10X with a fluorescence microscope using a variety of anti-DCX antibodies. Goat anti-DCX from Santa Cruz (A, 1/100 in PBS-Triton), guinea pig anti-DCX from Chemicon (now Millipore; B, 1/500 in PBS-Triton), and rabbit anti-DCX from Abcam (C, 1/1000 in PBS-Triton).

\section{RESULTS}

\section{Specificity of the Weak DCX Staining in OPC}

Figure 1 shows the difference in relative intensity of staining of cells in neurogenic areas (Figures $\mathbf{1 A - C}$ ) and non-neurogenic areas (Figures 1D-F). All pictures were taken with the same objectives, the same gain but exposure times were generally twice as long for non-neurogenic DCX labeling. Although, we have observed this weak DCX staining with different immunohistochemistry protocol variants in rat and mouse tissue, the best results appear to be dependent on a short 1-h postfixation period.

Figure 2A shows DCX immunostaining using a goat antiDCX from Santa Cruz (SC-8066) used by many researchers. Figures 2B,C show DCX immunostaining using respectively a guinea pig anti-DCX from Chemicon (AB5910) and a rabbit antiDCX from Abcam (Ab18723). These observations suggest that light DCX cell labeling outside of neurogenic zones is not specific to one primary antibody. In general, the original guinea pig anti-DCX from Chemicon (AB5910) produced brighter labeling but with slightly increased background. Because others and we typically use the Santa Cruz DCX primary antibodies, we also confirmed its specificity through the absence of staining after blocking the DCX primary antibody with the corresponding DCX immunizing peptide (Santa Cruz SC-8066P) that we also used to block the guinea pig anti-DCX (Figure 3). The absence of labeling observed in the presence of the immunizing peptide indicated that the primary anti-DCX antibody recognizes DCX protein. Figure 3 also shows the relative intensity of DCX in OPCs compared to the cells in the subgranular layer of the dentate gyrus. Together, these observations confirm that the weak 


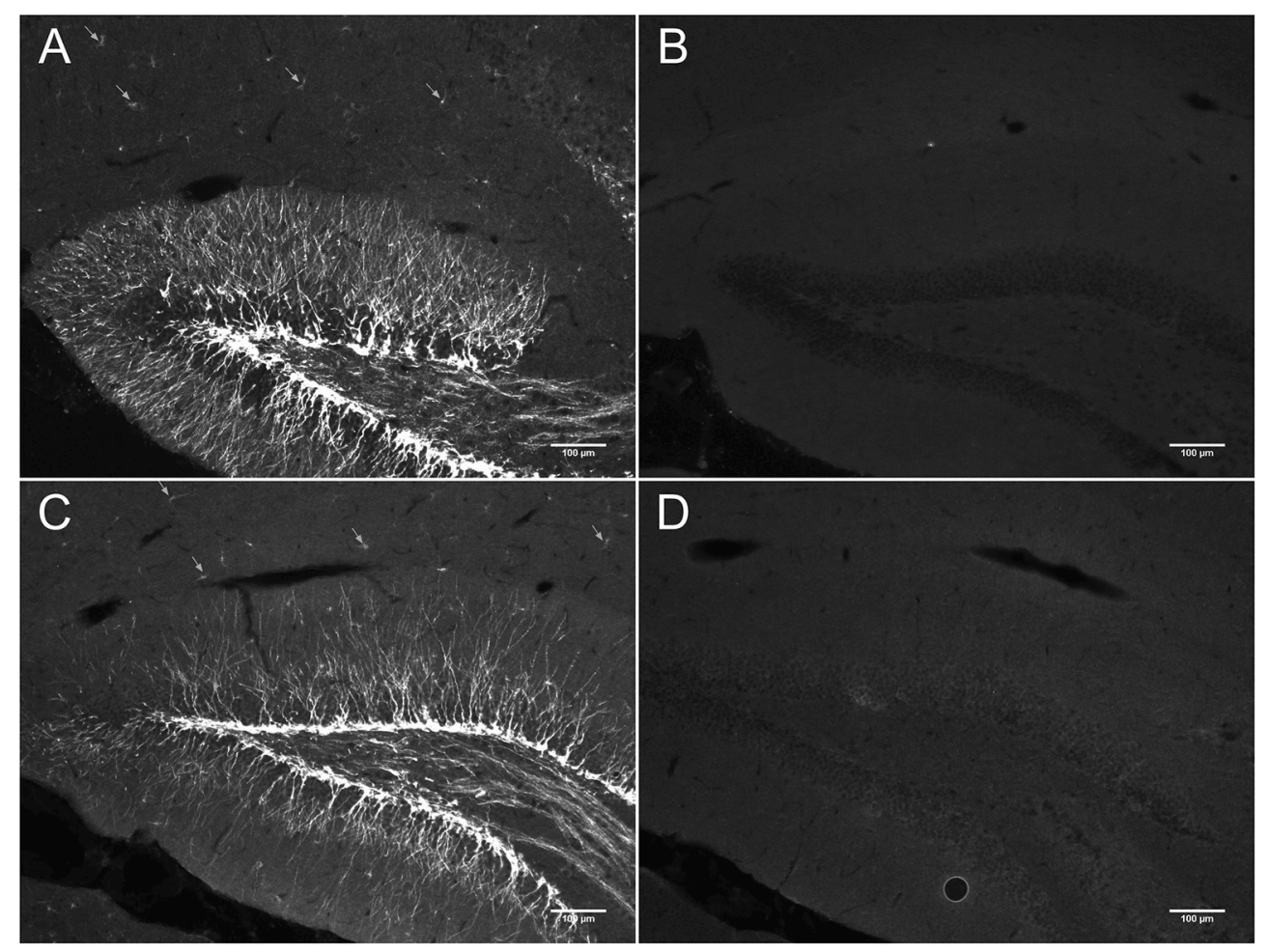

FIGURE 3 | DCX immunostaining in hippocampus of mouse brain with (B,D) and without anti-DCX peptide (A,C). Pictures were taken at 10X using a fluorescence microscope. Goat anti-DCX from Santa Cruz Biotechnology was used in images (A,B) and guinea pig anti-DCX from Chemicon (now Millipore) was used in images (C,D). Arrows show DCX staining in OPCs located outside of the known neurogenic zone that is the dentate gyrus of the hippocampus.
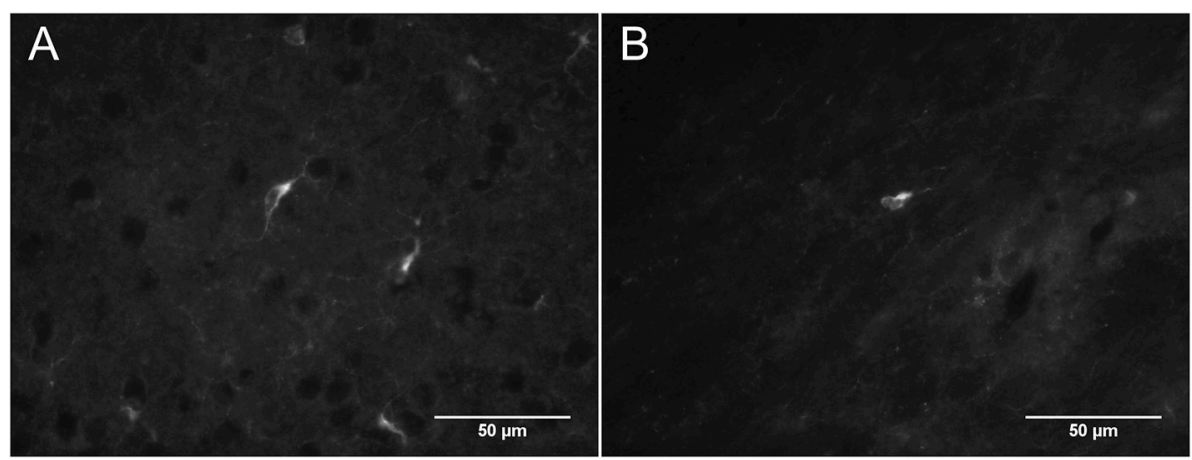

FIGURE 4 | (A,B) Two examples of DCX-positive cells outside of neurogenic zones: DCX immunostaining (guinea pig anti-DCX) is concentrated in one pole of the cell. Pictures were taken in the cortex at $40 \mathrm{X}$ with a fluorescence microscope.

DCX staining observed in OPCs throughout the mouse and rat brain is a specific and reproducible finding.

In DCX lightly stained cells, there is a characteristic higher intensity staining of one pole of the cell: this is very typical of the DCX in OPCs. The rest of the cell body is weakly stained while the membrane appears slightly more stained (Figure 4). The most intense staining is found at the hillock of the main branch of the cell processes. Most of the cell processes also appear to contain DCX with weaker staining being found in the finer processes. Most cells that are weakly stained for DCX are multipolar with a minority of cells that are bipolar or, more rarely, unipolar. In
DCX-labeled cell with a bipolar form, only one of the poles had intense DCX labeling, usually the one with the most processes. In instances where OPCs were newly divided, as demonstrated by $\mathrm{PDGFR}_{\alpha}$ labeling coupled with BrdU immunostaining, we observed early DCX labeling (Figure 5).

\section{Identity of Cells Labeled with DCX Outside Neurogenic Areas}

Virtually all DCX weakly stained cells were also labeled with $\mathrm{PDGFR}_{\alpha}$, an OPC marker (Figure 6). These doublelabeled cells are observed throughout the brain and follow 


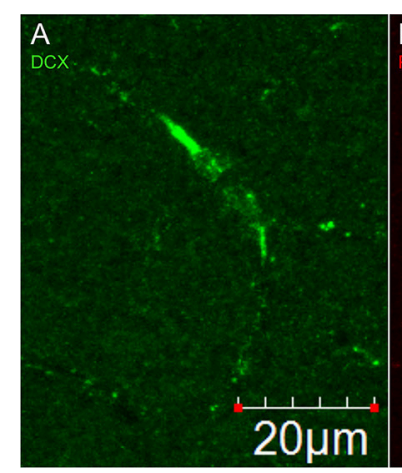

B

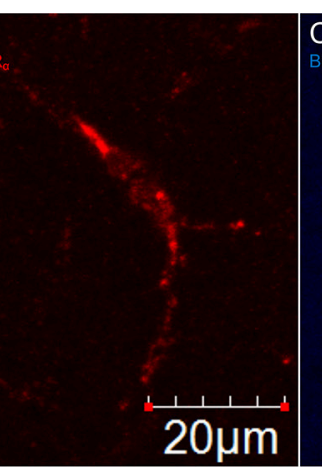

C BrdU
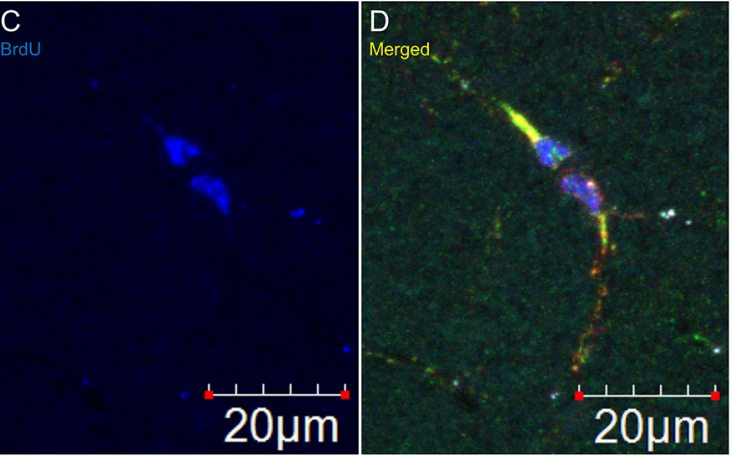

FIGURE 5 | DCX immunostaining appears after division of an OPC. Pictures taken in the cortex at 60X with a laser scan confocal microscope. DCX in green (A), $\mathrm{PDGFR}_{\alpha}$ in red (B), BrdU in blue (C), and merged (D).

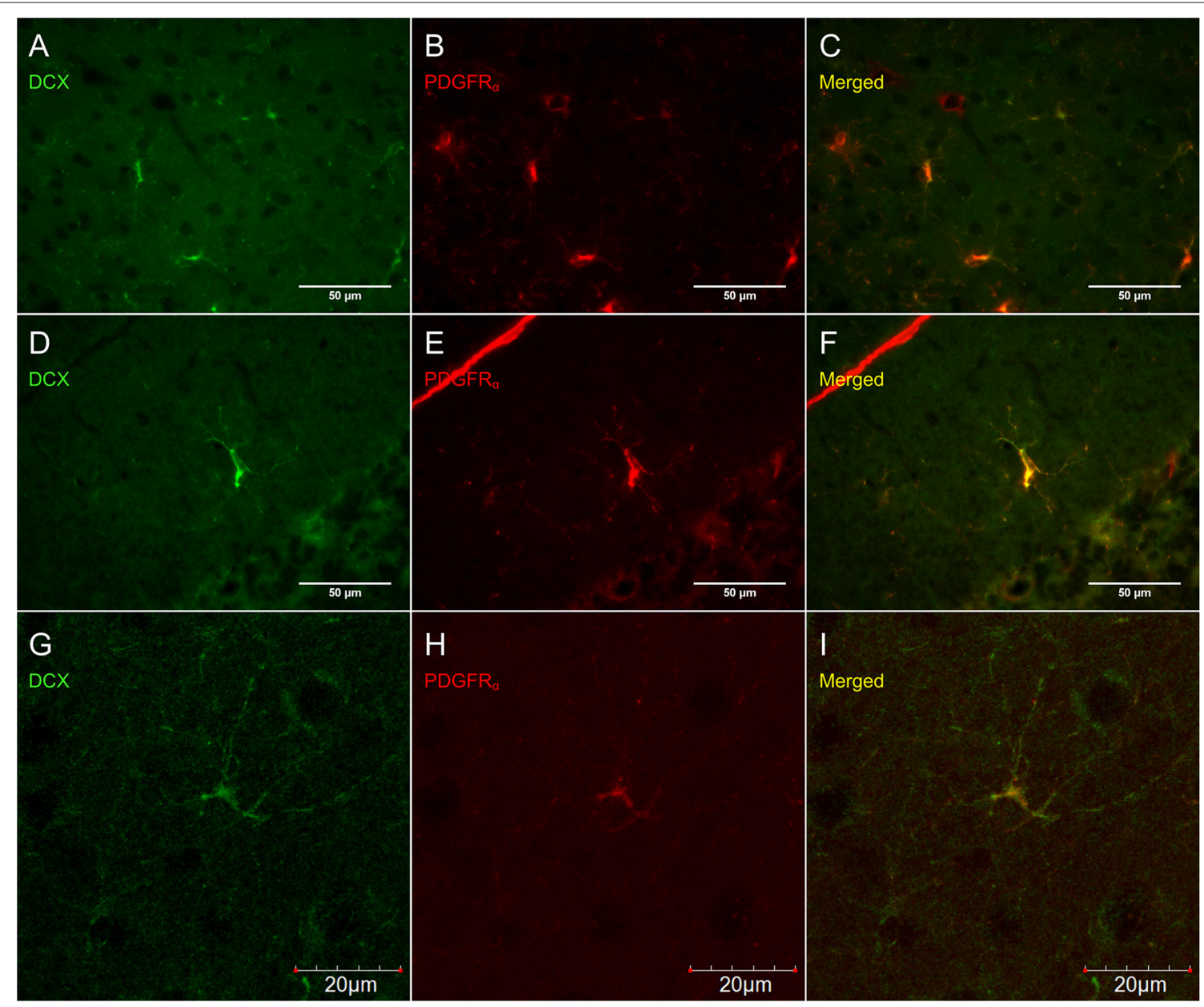

FIGURE 6 | DCX immunostaining (guinea pig anti-DCX) outside of neurogenic zones is co-localized with PDGFR (rat anti-PDGFR $_{\alpha}$ ), an OPC-marker. Pictures taken at 40x with a fluorescence microscope in the cortex $(\mathbf{A}-\mathbf{C})$ and in the cerebellum (D-F) and at 40x with a laser scan confocal microscope in the cortex (G-I). DCX in green (A,D,G), PDGFR $\alpha$ in red (B,E,H), and merged (C,F,I).

the usual distribution of OPCs. DCX lightly-labeled OPClike cells outside of neurogenic zones are co-localized with GFP in NG2-CreER:EYFP reporter mice (Figure 7). When tamoxifen is intraperitoneally injected into these mice, it induces a Cre-mediated recombination of the floxed sequences and EYFP expression is thus observed in NG2-positive cells. Since NG2 is also a marker of OPCs, this confirms that OPCs express DCX at least at some point in time, including when they 


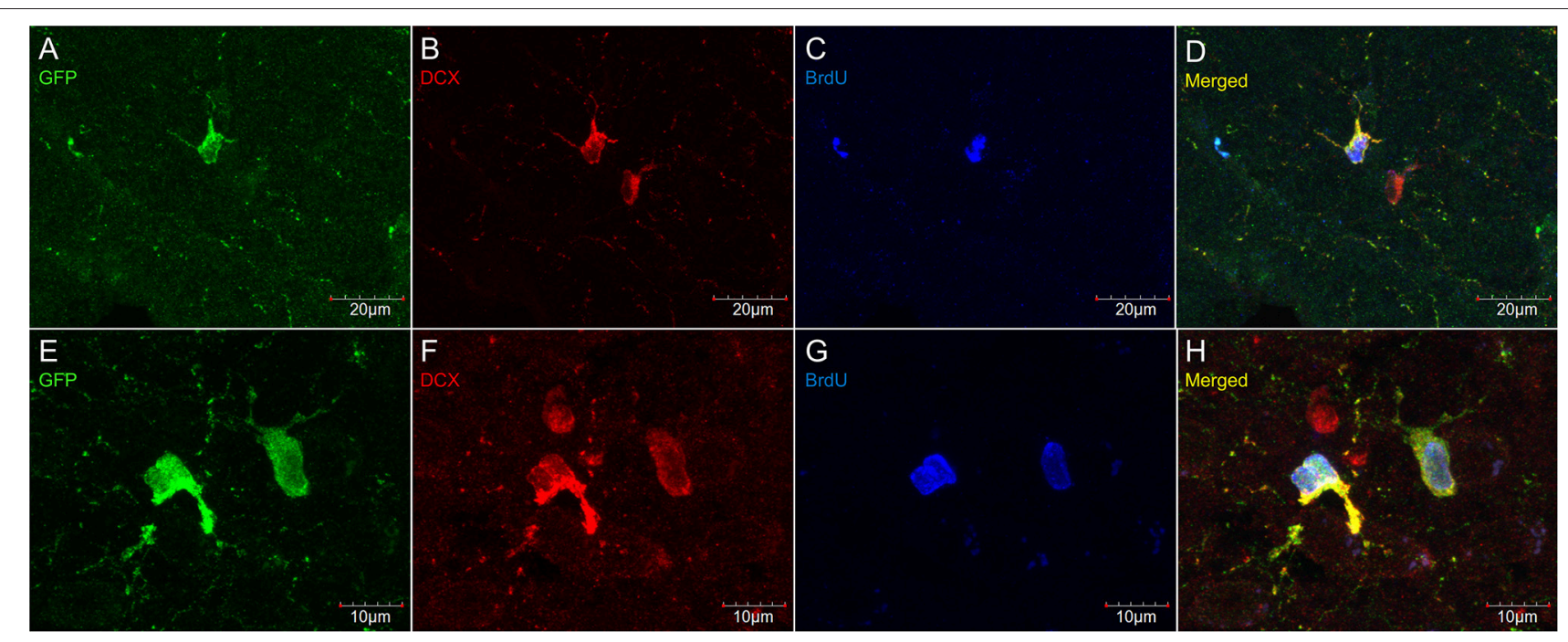

FIGURE 7 | DCX immunostaining (goat anti-DCX) in OPC-like cells outside of neurogenic zones is co-localized with GFP in NG2-CreER:EYFP reporter mice. Pictures taken in the cortex at 40X with a laser scan confocal microscope (A-D). Pictures taken in the cortex at 60X with a laser scan confocal microscope

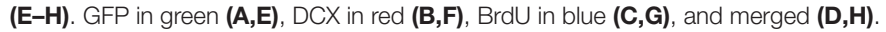
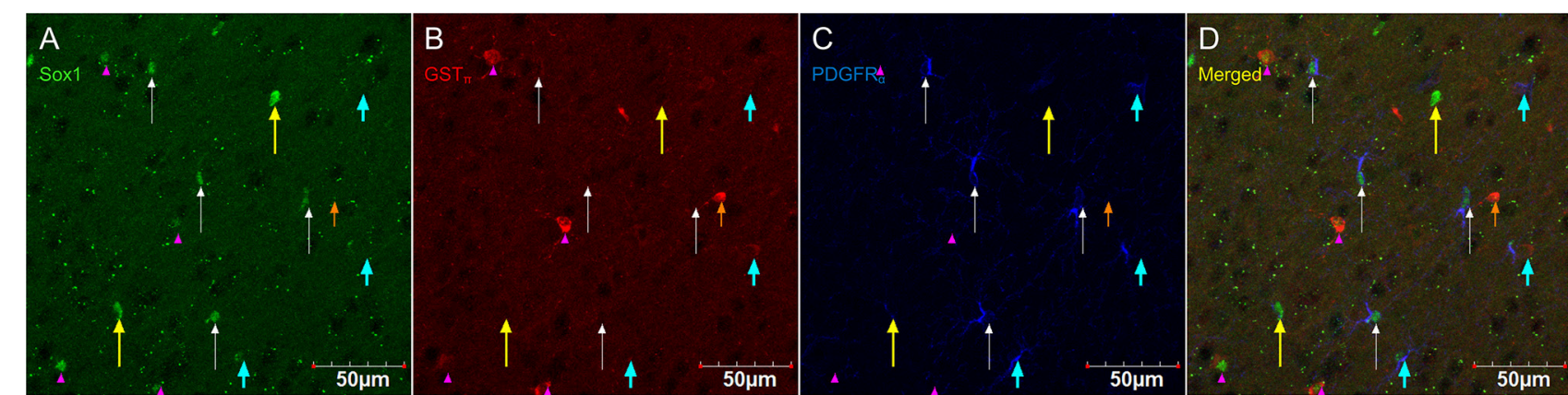

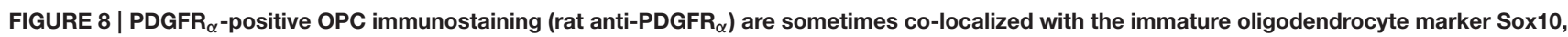
but never with the marker of mature oligodendrocytes $\mathbf{G S T}_{\pi}$. Pictures taken in the cortex at $40 \mathrm{X}$ using a laser scan confocal microscope. Sox10 in green (A),

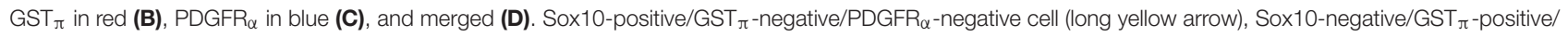

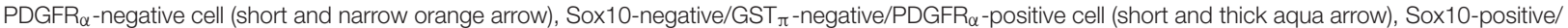
GST $_{\pi}$-positive/PDGFR ${ }_{\alpha}$-negative cell (long and narrow white arrow), and Sox10-positive/GST $\pi$-negative/PDGFR - -positive cell (pink arrow head).

have proliferated, as demonstrated by BrdU immunostaining (Figure 7).

Figure 8 shows that $\mathrm{PDGFR}_{\alpha}$-positive OPC immunostaining are sometimes co-localized with the immature oligodendrocyte marker Sox10 (Stolt et al., 2002), but never with the marker of mature oligodendrocytes GST $\pi$ (Deloulme et al., 2004; Polito and Reynolds, 2005; Nishiyama, 2007; Taupin, 2010). Similarly, DCX immunostaining outside of neurogenic zones are sometimes colocalized with Sox10 (Figure 9) but not with $\mathrm{GST}_{\pi}$ (Figure 10). Sox10 regulates myelin gene expression in oligodendrocytes and is therefore expressed by OPCs that are transitioning to a mature, myelinating oligodendroglial phenotype (Stolt et al., 2002; Liu et al., 2007). During that transition, some, but not all, adultbrain OPCs express Sox10 and conversely, some, but not all oligodendrocytes, express Sox10.

Some researchers have reported DCX labeling outside of neurogenic zones together with labeling for neuronal markers (for example NeuN; Nacher et al., 2001; Dayer et al., 2005; Luzzati et al., 2006; Xiong et al., 2008; Cai et al., 2009; Klempin et al., 2011; Werner et al., 2012; Saul et al., 2014). We have observed numerous instances of closely apposed OPC-neuron pairs (Figures 11C,F,G) that can appear in some instances as double-labeled cells (Figure 11H). These were found in outbred mice (CD-1; Figures 11A-F) as well as in the NG2-CreER:EYFP reporter mice (Figures 11F,G). The occurrence of OPC-neuron pairs has been mentioned previously (Butt et al., 2002; Sakry et al., 2011).

\section{DISCUSSION}

In the present report, we found that most OPCs express low levels of DCX in all parts of the brain where these cells are found. Low levels of DCX protein in OPCs is better 


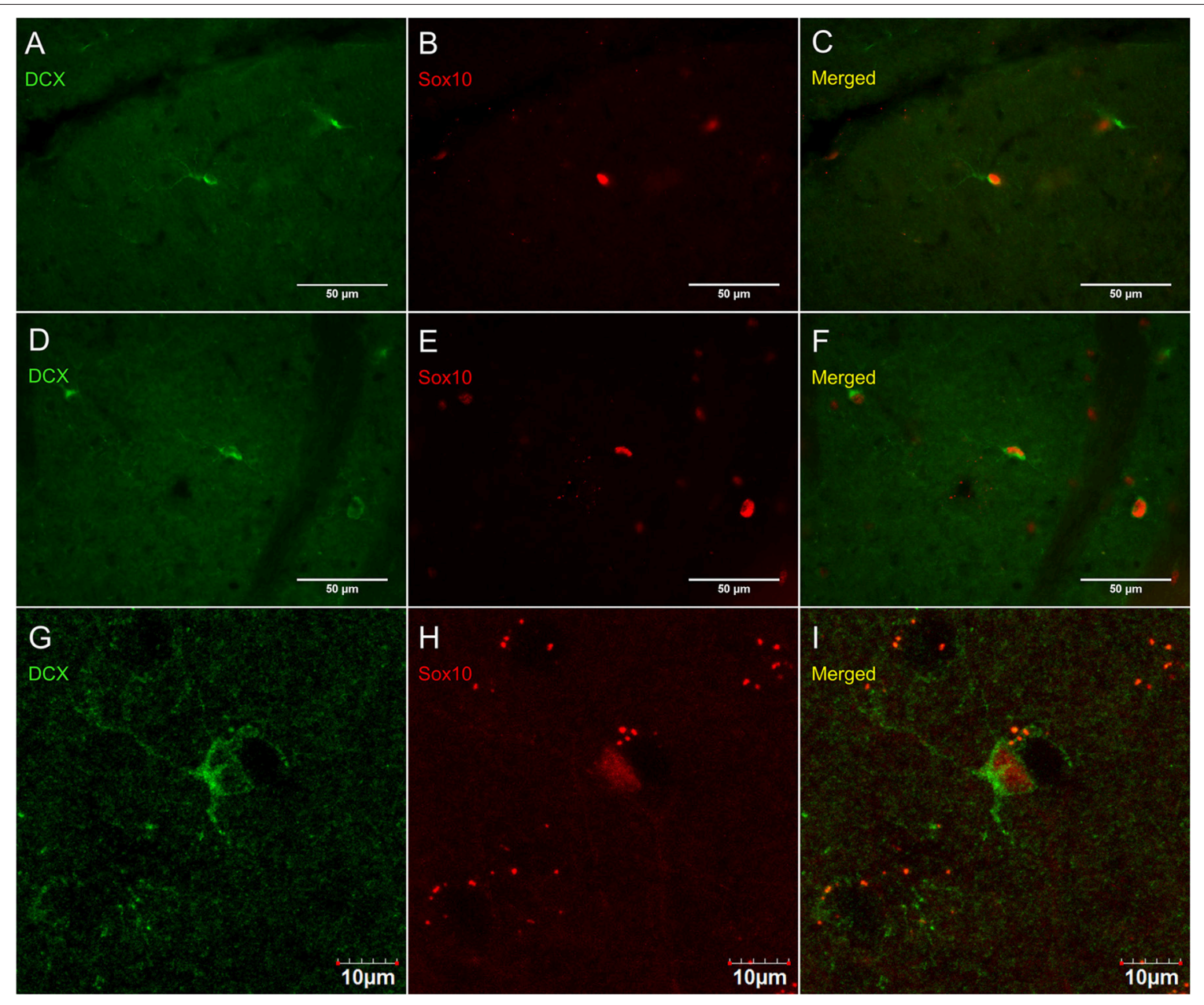

FIGURE 9 | DCX immunostaining (guinea pig anti-DCX) outside of neurogenic zones is sometimes co-localized with Sox10, a marker of immature oligodendrocytes. Pictures were taken at 40X using a fluorescence microscope with a fluorescence microscope in the cerebellum (A-C) and corpus callosum (D-F). Pictures were taken at 40X using a laser scan confocal microscope in the cortex (G-I). DCX in green (A,D,G), Sox10 in red (B,E,H), and merged (C,F,I).

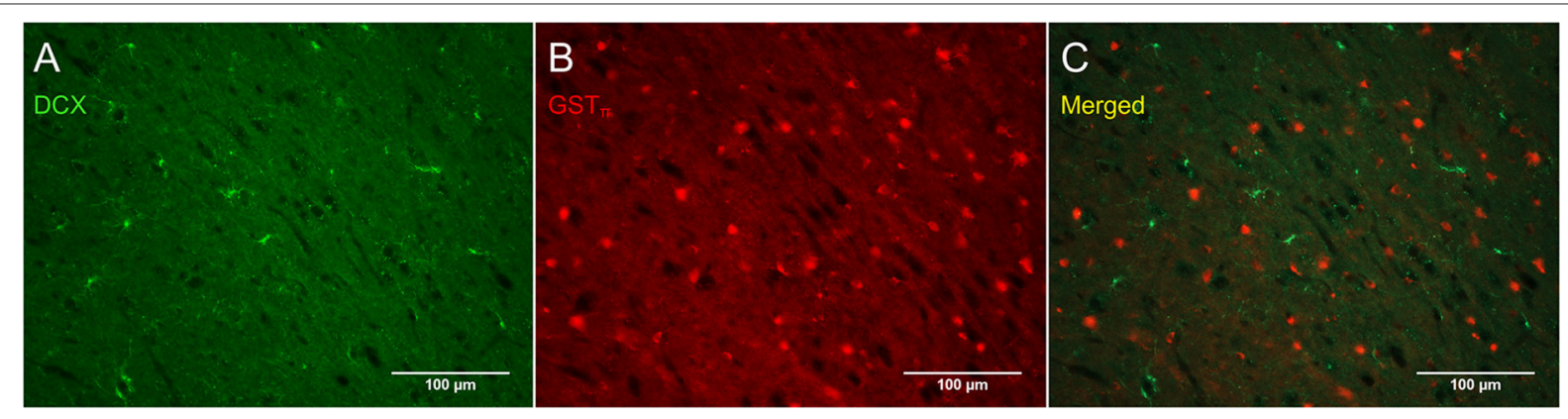

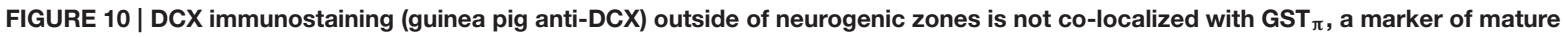
oligodendrocytes. Pictures were taken in the cortex at 20X with a fluorescence microscope. DCX in green (A), GST $\pi$ in red (B), and merged (C).

visualized in lightly fixed brain tissue. The intensity of labeling also varies between commercially available DCX antibodies. Although, we did not determine when exactly DCX starts being expressed in OPCs after division, the observation that virtually all OPCs appear to express DCX suggest that, in the adult rodent brain, OPCs express DCX sometime after division and continue to express DCX until they differentiate into myelinating oligodendrocytes. This conclusion is supported by the sparse number of OPCs that express both DCX and the transcription factor Sox10, which is crucial for the final transformation of 


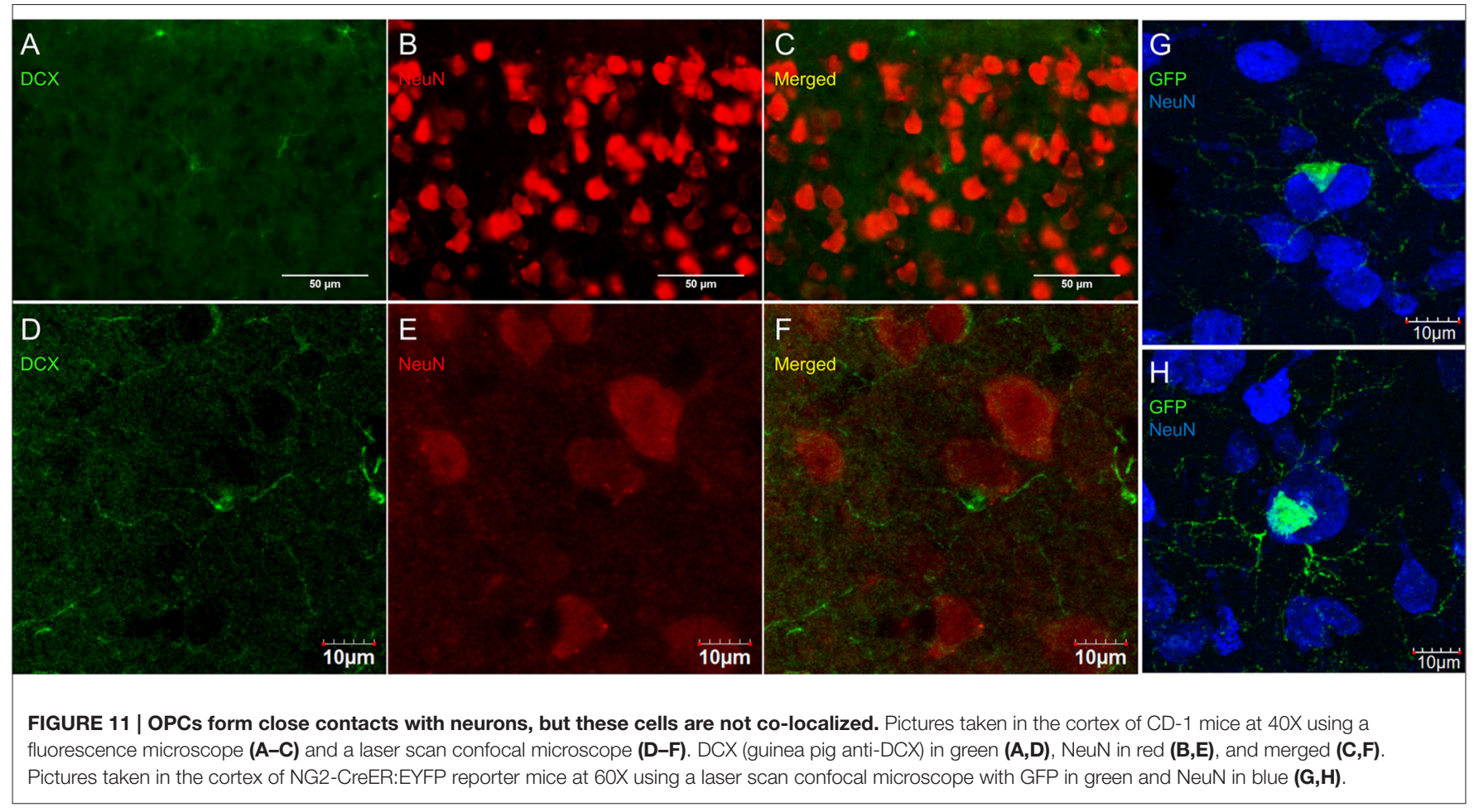

OPCs into myelinating oligodendrocytes (Stolt et al., 2002), and the absence of co-labeling of DCX together with $\mathrm{GST}_{\pi}$, a marker of mature myelinating oligodendrocytes (Tansey and Cammer, 1991; Tamura et al., 2007b; Simon et al., 2011).

Classically, DCX has been described as a selective marker of adult neurogenesis (Brown et al., 2003). As such, the observation of DCX-positive cells in various parts of the mammalian CNS previously led to the suggestion that new neurons are produced outside of the dentate gyrus and the subventricular zone (Dayer et al., 2005; Tamura et al., 2007a). In support of this hypothesis came reports that NG2-positive precursors are multipotent and can generate functional neurons (Belachew et al., 2003; Aguirre and Gallo, 2004; Aguirre et al., 2004; Dayer et al., 2005; Tamura et al., 2007a; Rivers et al., 2008; Zhu et al., 2008; Guo F. Z. et al., 2009, 2010; Robins et al., 2013).

Because of these reports, we examined if DCX-positive found outside of neurogenic zones also express mature or immature neuronal markers. We examined patterns of labeling using antibodies against Pax6-a paired box gene which is expressed by immature glutamatergic neurons (Bayatti et al., 2008), Pax2a paired box gene expressed in GABAergic neurons (Batista and Lewis, 2008), and HuCD and Rbfox3 (NeuN)-markers of mature neurons. We found some very rare examples of colabeling of lightly stained DCX cells either with Pax2, Rbfox3, or $\mathrm{HuCD}$ but that did not express OPC markers such as PDGFR ${ }_{\alpha}$. Sometimes the closely apposed OPC-neuron pairs could be interpreted as double-labeled cells. In these instances, an OPC and a neuron could be superimposed in the field of view, as shown in Figure 11. While these observations do not rule out the possibility that OPCs can generate mature neurons, it may help explain the conclusion drawn by others that all DCXpositive cells, including those located outside of the dentate gyrus and subventricular zone, have neuronal attributes. These observations do not rule out the possibility of OPC-derived neurogenesis but they suggest additional caution to exclude other possibilities (see further discussion of this issue in Dimou and Gallo, 2015; Feliciano et al., 2015).

Finally, the question remains as to the role of doublecortin in OPCs. Since DCX is a microtubule-associated protein and because DCX-positive cells outside of neurogenic zones do not co-express mature neuronal markers, it is unlikely to be associated with a potential for OPCs to differentiate into neurons. It may, however, be involved in their migration over small distances as they monitor a unique territory that is not shared by other OPCs (Hughes et al., 2013). Furthermore, recent studies in missense DCX gene expression suggest a role in tubulin organization that could be associated with migration but also with process extension to establish and remodel the synaptic connections between neurons and OPCs (Tsai et al., 2016). This is significant since OPCs are known to form glutamatergic and GABAergic synapses with neurons (Bergles et al., 2000; Lin and Bergles, 2004). Therefore, this report as well as others suggest that it is time to stop viewing DCX as a marker of newly generated neurons but, rather, as a marker of cells that are undergoing migration or other forms of process reorganization.

\section{AUTHOR CONTRIBUTIONS}

JJB and CM contributed equally to the design analysis and preparation of the manuscript. 


\section{ACKNOWLEDGMENTS}

CM received a grant from the Natural Sciences and Engineering Council of Canada, and an equipment grant from the Canadian Foundation for Innovation and the Ontario

\section{REFERENCES}

Aguirre, A. A., Chittajallu, R., Belachew, S., and Gallo, V. (2004). NG2-expressing cells in the subventricular zone are type C-like cells and contribute to interneuron generation in the postnatal hippocampus. J. Cell Biol. 165, 575-589. doi: 10.1083/jcb.200311141

Aguirre, A., and Gallo, V. (2004). Postnatal neurogenesis and gliogenesis in the olfactory bulb from NG2-expressing progenitors of the subventricular zone. J. Neurosci. 24, 10530-10541. doi: 10.1523/JNEUROSCI.3572-04.2004

Altman, J., and Das, G. D. (1964). Autoradiographic examination of the effects of enriched environment on the rate of glial multiplication in the adult rat brain. Nature 204, 1161-1163. doi: 10.1038/2041161a0

Alvarez-Buylla, A., and Garcia-Verdugo, J. M. (2002). Neurogenesis in adult subventricular zone. J. Neurosci. 22, 629-634.

Batista, M. F., and Lewis, K. E. (2008). Pax2/8 act redundantly to specify glycinergic and GABAergic fates of multiple spinal interneurons. Dev. Biol. 323, 88-97. doi: 10.1016/j.ydbio.2008.08.009

Bayatti, N., Sarma, S., Shaw, C., Eyre, J. A., Vouyiouklis, D. A., Lindsay, S., et al. (2008). Progressive loss of PAX6, TBR2, NEUROD and TBR1 mRNA gradients correlates with translocation of EMX2 to the cortical plate during human cortical development. Eur. J. Neurosci. 28, 1449-1456. doi: 10.1111/j.1460-9568.2008.06475.x

Belachew, S., Chittajallu, R., Aguirre, A. A., Yuan, X., Kirby, M., Anderson, S., et al. (2003). Postnatal NG2 proteoglycan-expressing progenitor cells are intrinsically multipotent and generate functional neurons. J. Cell Biol. 161, 169-186. doi: 10.1083/jcb.200210110

Bergles, D. E., Roberts, J. D., Somogyi, P., and Jahr, C. E. (2000). Glutamatergic synapses on oligodendrocyte precursor cells in the hippocampus. Nature 405, 187-191. doi: 10.1038/35012083

Boulanger, J. J., and Messier, C. (2014). From precursors to myelinating oligodendrocytes: contribution of intrinsic and extrinsic factors to white matter plasticity in the adult brain. Neuroscience 269, 343-366. doi: 10.1016/j.neuroscience.2014.03.063

Boulanger, J. J., Staines, W. A., LeBlanc, V., Khoo, E.L., Liang, J., and Messier, C. (2016). A simple histological technique to improve immunostaining when using DNA denaturation for BrdU labelling. J. Neurosci. Methods 259, 40-46. doi: 10.1016/j.jneumeth.2015.11.006

Brown, J. P., Couillard-Despres, S., Cooper-Kuhn, C. M., Winkler, J., Aigner, L., and Kuhn, H. G. (2003). Transient expression of doublecortin during adult neurogenesis. J. Comp. Neurol. 467, 1-10. doi: 10.1002/cne.10874

Butt, A. M., Kiff, J., Hubbard, P., and Berry, M. (2002). Synantocytes: new functions for novel NG2 expressing glia. J. Neurocytol. 31, 551-565.

Cai, Y., Xiong, K., Chu, Y., Luo, D.W., Luo, X.G., Yuan, X.Y., et al. (2009). Doublecortin expression in adult cat and primate cerebral cortex relates to immature neurons that develop into GABAergic subgroups. Exp. Neurol. 216, 342-356. doi: 10.1016/j.expneurol.2008.12.008

Cameron, H.A., Woolley, C.S., McEwen, B.S., and Gould, E. (1993). Differentiation of newly born neurons and glia in the dentate gyrus of the adult rat. Neuroscience 56, 337-344. doi: 10.1016/0306-4522(93)90335-D

Clarke, L. E., Young, K. M., Hamilton, N. B., Li, H., Richardson, W. D., and Attwell, D. (2012). Properties and fate of oligodendrocyte progenitor cells in the corpus callosum, motor cortex, and piriform cortex of the mouse. J. Neurosci. 32, 8173-8185. doi: 10.1523/JNEUROSCI.0928-12.2012

Dawson, M. R., Polito, A., Levine, J. M., and Reynolds, R. (2003). NG2expressing glial progenitor cells: an abundant and widespread population of cycling cells in the adult rat CNS. Mol. Cell. Neurosci. 24, 476-488. doi: 10.1016/S1044-7431(03)00210-0

Dayer, A. G., Cleaver, K. M., Abouantoun, T., and Cameron, H. A. (2005). New GABAergic interneurons in the adult neocortex and striatum are generated from different precursors. J. Cell Biol. 168, 415-427. doi: 10.1083/jcb.200407053
Research Fund-Research Infrastructure program. We also acknowledge the support of the Faculty of Social Sciences of the University of Ottawa. JJB received a Graduate Research Fellowship from the Natural Sciences and Engineering Council of Canada.

De Biase, L. M., Nishiyama, A., and Bergles, D. E. (2010). Excitability and synaptic communication within the oligodendrocyte lineage. J. Neurosci. 30, 3600-3611. doi: 10.1523/JNEUROSCI.6000-09.2010

Deloulme, J. C., Raponi, E., Gentil, B. J., Bertacchi, N., Marks, A., Labourdette, G., et al. (2004). Nuclear expression of S100B in oligodendrocyte progenitor cells correlates with differentiation toward the oligodendroglial lineage and modulates oligodendrocytes maturation. Mol. Cell. Neurosci. 27, 453-465. doi: 10.1016/j.mcn.2004.07.008

Dimou, L., and Gallo, V. (2015). NG2-glia and their functions in the central nervous system. Glia 63, 1429-1451. doi: 10.1002/glia.22859

Dimou, L., Simon, C., Kirchhoff, F., Takebayashi, H., and Gotz, M. (2008) Progeny of olig2-expressing progenitors in the gray and white matter of the adult mouse cerebral cortex. J. Neurosci. 28, 10434-10442. doi: 10.1523/JNEUROSCI.2831-08.2008

Ehninger, D., Wang, L. P., Klempin, F., Romer, B., Kettenmann, H., and Kempermann, G. (2011). Enriched environment and physical activity reduce microglia and influence the fate of NG2 cells in the amygdala of adult mice. Cell Tissue Res. 345, 69-86. doi: 10.1007/s00441-011-1200-Z

Feliciano, D. M., Bordey, A., and Bonfanti, L. (2015). Noncanonical sites of adult neurogenesis in the mammalian brain. Cold Spring Harb. Perspect. Biol. 7:a018846. doi: 10.1101/cshperspect.a018846

Francis, F., Koulakoff, A., Boucher, D., Chafey, P., Schaar, B., Vinet, M.C. et al. (1999). Doublecortin is a developmentally regulated, microtubuleassociated protein expressed in migrating and differentiating neurons. Neuron 23, 247-256. doi: 10.1016/S0896-6273(00)80777-1

Gallo, V., Mangin, J. M., Kukley, M., and Dietrich, D. (2008). Synapses on NG2-expressing progenitors in the brain: multiple functions ? J. Physiol. 586, 3767-3781. doi: 10.1113/jphysiol.2008.158436

Gleeson, J. G., Lin, P. T., Flanagan, L. A., and Walsh, C. A. (1999). Doublecortin is a microtubule-associated protein and is expressed widely by migrating neurons. Neuron 23, 257-271. doi: 10.1016/S0896-6273(00)80778-3

Guo, F., Maeda, Y., Ma, J., Xu, J., Horiuchi, M., Miers, L., et al. (2010). Pyramidal neurons are generated from oligodendroglial progenitor cells in adult piriform cortex. J. Neurosci. 30, 12036-12049. doi: 10.1523/JNEUROSCI.1360-10.2010

Guo, F. Z., Ma, J., McCauley, E., Bannerman, P., and Pleasure, D. (2009). Early postnatal proteolipid promoter-expressing progenitors produce multilineage cells in vivo. J. Neurosci. 29, 7256-7270. doi: 10.1523/JNEUROSCI.5653-08.2009

Guo, F. Z., Maeda, Y., Ma, J., Xu, J., Horiuchi, M., Miers, L., et al. (2010). Pyramidal neurons are generated from oligodendroglial progenitor cells in adult piriform cortex. J. Neurosci. 30, 12036-12049. doi: 10.1523/JNEUROSCI.1360-10.2010

Hughes, E. G., Kang, S. H., Fukaya, M., and Bergles, D. E. (2013). Oligodendrocyte progenitors balance growth with self-repulsion to achieve homeostasis in the adult brain. Nat. Neurosci. 16, 668-676. doi: 10.1038/nn.3390

Kang, S. H., Fukaya, M., Yang, J. K., Rothstein, J. D., and Bergles, D. E. (2010). NG2 ${ }^{+}$CNS glial progenitors remain committed to the oligodendrocyte lineage in postnatal life and following neurodegeneration. Neuron 68, 668-681. doi: 10.1016/j.neuron.2010.09.009

Kaplan, M. S., and Bell, D. H. (1984). Mitotic neuroblasts in the 9-day-old and 11-month-old rodent hippocampus. J. Neurosci. 4, 1429-1441.

Klempin, F., Kronenberg, G., Cheung, G., Kettenmann, H., and Kempermann, G. (2011). Properties of doublecortin-(DCX)-expressing cells in the piriform cortex compared to the neurogenic dentate gyrus of adult mice. PLoS ONE 6:e25760. doi: 10.1371/journal.pone.0025760

Komitova, M., Zhu, X., Serwanski, D. R., and Nishiyama, A. (2009). NG2 cells are distinct from neurogenic cells in the postnatal mouse subventricular zone. $J$. Comp. Neurol. 512, 702-716. doi: 10.1002/cne.21917

Kuhn, H. G., Dickinson-Anson, H., and Gage, F. H. (1996). Neurogenesis in the dentate gyrus of the adult rat: age-related decrease of neuronal progenitor proliferation. J. Neurosci. 16, 2027-2033. 
Kukley, M., Nishiyama, A., and Dietrich, D. (2010). The fate of synaptic input to NG2 glial cells: neurons specifically downregulate transmitter release onto differentiating oligodendroglial cells. J. Neurosci. 30, 8320-8331. doi: 10.1523/JNEUROSCI.0854-10.2010

Larson, V. A., Zhang, Y., and Bergles, D. E. (2016). Electrophysiological properties of $\mathrm{NG}+$ cells: matching physiological studies with gene expression profiles. Brain Res. 1638, 138-160. doi: 10.1016/j.brainres.2015. 09.010

Lin, S. C., and Bergles, D. E. (2004). Synaptic signaling between GABAergic interneurons and oligodendrocyte precursor cells in the hippocampus. Nat. Neurosci. 7, 24-32. doi: 10.1038/nn1162

Liu, Z., Hu, X., Cai, J., Liu, B., Peng, X., Wegner, M., et al. (2007). Induction of oligodendrocyte differentiation by Olig2 and Sox10: evidence for reciprocal interactions and dosage-dependent mechanisms. Dev. Biol. 302, 683-693. doi: 10.1016/j.ydbio.2006.10.007

Lois, C., and Alvarez-Buylla, A. (1994). Long-distance neuronal migration in the adult mammalian brain. Science 264, 1145-1148. doi: 10.1126/science.8178174

Luzzati, F., De Marchis, S., Fasolo, A., and Peretto, P. (2006). Neurogenesis in the caudate nucleus of the adult rabbit. J. Neurosci. 26, 609-621. doi: 10.1523/JNEUROSCI.4371-05.2006

Messier, B., Leblond, C. P., and Smart, I. (1958). Presence of DNA synthesis and mitosis in the brain of young adult mice. Exp. Cell Res. 14, 224-226. doi: 10.1016/0014-4827(58)90235-0

Nacher, J., Crespo, C., and McEwen, B. S. (2001). Doublecortin expression in the adult rat telencephalon. Eur. J. Neurosci. 14, 629-644. doi: 10.1046/j.0953-816x.2001.01683.x

Nishiyama, A. (2007). Polydendrocytes: NG2 cells with many roles in development and repair of the CNS. Neuroscientist 13, 62-76. doi: $10.1177 / 1073858406295586$

Nishiyama, A., Boshans, L., Goncalves, C. M., Wegrzyn, J., and Patel, K. D. (2016). Lineage, fate, and fate potential of NG2-glia. Brain Res. 1638, 116-128. doi: 10.1016/j.brainres.2015.08.013

Nishiyama, A., Watanabe, M., Yang, Z., and Bu, J. (2002). Identity, distribution, and development of polydendrocytes: NG2-epxressing glial cells. J. Neurocytol. 31, 437-455. doi: 10.1023/A:1025783412651

Polito, A., and Reynolds, R. (2005). NG2-expressing cells as oligodendrocyte progenitors in the normal and demyelinated adult central nervous system. J. Anat. 207, 707-716. doi: 10.1111/j.1469-7580.2005. 00454.x

Psachoulia, K., Jamen, F., Young, K. M., and Richardson, W. D. (2009). Cell cycle dynamics of NG2 cells in the postnatal and ageing brain. Neuron Glia Biol. 5, 57-67. doi: 10.1017/S1740925X09990354

Richardson, W. D., Young, K. M., Tripathi, R. B., and McKenzie, I. (2011). NG2glia as multipotent neural stem cells: fact or fantasy? Neuron 70, 661-673. doi: 10.1016/j.neuron.2011.05.013

Rivers, L. E., Young, K. M., Rizzi, M., Jamen, F., Psachoulia, K., Wade, A., et al. (2008). PDGFRA/NG2 glia generate myelinating oligodendrocytes and piriform projection neurons in adult mice. Nat. Neurosci. 11, 1392-1401. doi: $10.1038 / \mathrm{nn} .2220$

Robins, S. C., Trudel, E., Rotondi, O., Liu, X., Djogo, T., Kryzskaya, D., et al. (2013). Evidence for NG2-glia Derived, Adult-Born Functional Neurons in the Hypothalamus. PLOS ONE 8:e78236. doi: 10.1371/journal.pone. 0078236

Sakry, D., Karram, K., and Trotter, J. (2011). Synapses between NG2 glia and neurons. J. Anat. 219, 2-7. doi: 10.1111/j.1469-7580.2011.01359.x

Saul, M. L., Helmreich, D. L., Callahan, L. M., and Fudge, J. L. (2014). Differences in amygdala cell proliferation between adolescent and young adult rats. Dev. Psychobiol. 56, 517-528. doi: 10.1002/dev.21115

Simon, C., Gotz, M., and Dimou, L. (2011). Progenitors in the adult cerebral cortex: cell cycle properties and regulation by physiological stimuli and injury. Glia 59, 869-881. doi: 10.1002/glia.21156
Stanfield, B.B., and Trice, J.E. (1988). Evidence that granule cells generated in the dentate gyrus of adult rats extend axonal projections. Exp. Brain Res. 72, 399-406. doi: 10.1007/BF00250261

Stolt, C. C., Rehberg, S., Ader, M., Lommes, P., Riethmacher, D., Schachner, M., et al. (2002). Terminal differentiation of myelin-forming oligodendrocytes depends on the transcription factor Sox10. Genes Dev. 16, 165-170. doi: 10.1101/gad.215802

Tamura, Y., Kataoka, Y., Cui, Y., Takamori, Y., Watanabe, Y., and Yamada, H. (2007a). Multi-directional differentiation of doublecortin- and NG2immunopositive progenitor cells in the adult rat neocortex in vivo. Eur. J. Neurosci. 25, 3489-3498. doi: 10.1111/j.1460-9568.2007.05617.x

Tamura, Y., Kataoka, Y., Cui, Y., Takamori, Y., Watanabe, Y., and Yamada, H. (2007b). Intracellular translocation of glutathione S-transferase pi during oligodendrocyte differentiation in adult rat cerebral cortex in vivo. Neuroscience 148, 535-540. doi: 10.1016/j.neuroscience.2007.06.026

Tansey, F. A., and Cammer, W. (1991). A pi form of glutathione-S-transferase is a myelin-and oligodendrocyte-associated enzyme in mouse brain. J. Neurochem. 57, 95-102. doi: 10.1111/j.1471-4159.1991.tb02104.x

Taupin, P. (2010). Thirteen compounds promoting oligodendrocyte progenitor cell differentiation and remyelination for treating multiple sclerosis: WO2010054307. Expert Opin. Ther. Pat. 20, 1767-1773. doi: $10.1517 / 13543776.2010 .528393$

Tsai, M. H., Kuo, P. W., Myers, C. T., Li, S. W., Lin, W. C., Fu, T. Y., et al. (2016). A novel DCX missense mutation in a family with X-linked lissencephaly and subcortical band heterotopia syndrome inherited from a low-level somatic mosaic mother: genetic and functional studies. Eur. J. Paediatr. Neurol. 20, 788-794. doi: 10.1016/j.ejpn.2016.05.010

Viganò, F., and Dimou, L. (2016). The heterogeneous nature of NG2-glia. Brain Res. 1638, 129-137. doi: 10.1016/j.brainres.2015.09.012

Werner, L., Müller-Fielitz, H., Ritzal, M., Werner, T., Rossner, M., and Schwaninger, M. (2012). Involvement of doublecortin-expressing cells in the arcuate nucleus in body weight regulation. Endocrinology 153, 2655-2664. doi: 10.1210/en.2011-1760

Xiong, K., Luo, D.W., Patrylo, P. R., Luo, X.G., Struble, R. G., Clough, R. W., et al. (2008). Doublecortin-expressing cells are present in layer II across the adult guinea pig cerebral cortex: partial colocalization with mature interneuron markers. Exp. Neurol. 211, 271-282. doi: 10.1016/j.expneurol.2008. 02.003

Zamboni, L., and Demartin,.C. (1967). Buffered picric acid-formaldehyde - a new rapid fixative for electron microscopy. J. Cell Biol. 35:A148.

Zhu, X., Hill, R. A., Dietrich, D., Komitova, M., Suzuki, R., and Nishiyama, A. (2011). Age-dependent fate and lineage restriction of single NG2 cells. Development $138,745-753$. doi: 10.1242/dev.047951

Zhu, X., Bergles, D. E., and Nishiyama, A. (2008). NG2 cells generate both oligodendrocytes and gray matter astrocytes. Development 135, 145-157. doi: $10.1242 / \mathrm{dev} .004895$

Conflict of Interest Statement: The authors declare that the research was conducted in the absence of any commercial or financial relationships that could be construed as a potential conflict of interest.

The reviewer $\mathrm{CM}$ and handling Editor declared their shared affiliation, and the handling Editor states that the process nevertheless met the standards of a fair and objective review.

Copyright $\odot 2017$ Boulanger and Messier. This is an open-access article distributed under the terms of the Creative Commons Attribution License (CC BY). The use, distribution or reproduction in other forums is permitted, provided the original author(s) or licensor are credited and that the original publication in this journal is cited, in accordance with accepted academic practice. No use, distribution or reproduction is permitted which does not comply with these terms. 